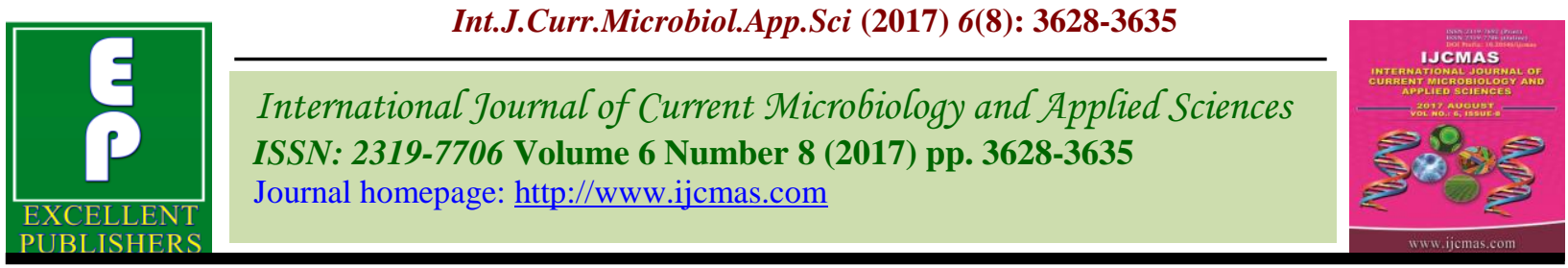

Original Research Article

https://doi.org/10.20546/ijcmas.2017.608.437

\title{
Evaluation of Substrates for Mass Production of Trichoderma harzianum and its Compatibility with Chlorpyrifos + Cypermethrin
}

\author{
N.S. Siddhartha ${ }^{1}$, K.V. Amara ${ }^{1}$, K.A. Ramya Mol ${ }^{2}$, K.A. Saju ${ }^{2 *}$, \\ K.N. Harsha ${ }^{2}$, P. Sharanappa ${ }^{1}$ and K. Pradip Kumar ${ }^{2}$ \\ ${ }^{1}$ Department of Botany, Post Graduate Centre, University of Mysore, \\ Hemagangothri 573220, Karnataka, India \\ ${ }^{2}$ Indian Cardamom Research Institute, Regional Station, Spices Board, \\ Sakleshpur 573134, Karnataka, India \\ *Corresponding author
}

\section{A B S T R A C T}

Coir pith compost, rice husk and sugarcane bagasse with and without $5 \%$ Jaggery solution as nutritional supplement was evaluated for the mass production of Trichoderma harzianum in comparison with coffee husk (parchment). On incubation up to 60 days,

Keywords

Chlorpyrifos, compatibility, Cypermethrin, Mass production, Substrates and Trichoderma.

Article Info

Accepted: 27 June 2017 Available Online: 10 August 2017 maximum number of propagules were recorded in coir pith compost $\left(43 \times 10^{10}\right)$, coir pith compost $+5 \%$ jaggery $\left(32.33 \times 10^{10}\right)$ and sugarcane bagasse $\left(21 \times 10^{10}\right)$ followed by rice husk $\left(38 \times 10^{10}\right)$ and rice husk $+5 \%$ jaggery $\left(23.33 \times 10^{10}\right)$. Coir pith compost and sugarcane bagasse recorded more population than other substrates and hence could be used in mass production. In another experiment, the compatibility of $T$. harzianum and insecticide combination, Chlorpyrifos $50 \%$ + Cypermethrin $5 \%$ was studied by poisoned food technique on PDA medium at concentrations of 55, 83, 110, 138, 165, 193 and 220 ppm. In the first set, the insecticide was added to the autoclaved medium (hence not heated) and in the second set the insecticide was autoclaved along with the medium. In both the cases, the colony growth was very slow initially for 5 days, however continued to grow as evident from the measurements on 10th and 15th day. Thus the insecticide was partially compatible with $T$. harzianum in in-vitro studies at all the concentration levels. Later, T. harzianum and Chlorpyrifos + Cypermethrin were incorporated into soil taken in containers so as to get the above insecticide concentrations and studied the compatibility by monitoring the population by serial dilution plate technique. After 30 days, it was found that the propagules in all the insecticide concentrations were on par with each other. Hence it is implied that the insecticide did not affect the population of T. harzianum in in-vivo conditions and found compatible for field application.

\section{Introduction}

Trichoderma harzianum has been identified as the potential biocontrol agent for soil borne disease management in black pepper, cardamom and ginger. Several studies were conducted to evaluate various substrates for its mass production (Rini et al., 2007; Prakash et al., 1999; Saju et al., 2002). Coffee husk
(Parchment) is considered as a very good substrate for the mass production and field application especially in the Western Ghats area of Karnataka. However, during offseasons there is scarcity of coffee husk and an alternative is sought for uninterrupted production of the bioagent formulation. 
Therefore, this study was conducted to evaluate other organic substrates suitable for mass multiplication of $T$. harzianum. Attempts were also made to enhance the population on these substrates using nutritional supplements.

For effective management of diseases, the compatibility of potential bioagents with insecticides is essential (Ashwini et al., 2012). Integration of compatible bioagent with pesticides may enhance the effectiveness of disease control and provide better management of soil borne diseases (Vinit et al., 2012; Thiruchchelvan et al., 2013; Saxena et al., 2014). In black pepper, the insecticide combination of Chlorpyrifos $50 \%$ and Cypermethrin $5 \%$ is being used as drench to control mealy bugs and termites. It is established that the Chlorpyrifos is compatible with $T$. harzianum (Stephen et al., 2000). The compatibility of Cypermethrin with $T$. harzianum is not studied so for. In view of the above, a study was undertaken to evaluate the compatibility of $T$. harzianum and combination of insecticide Chlorpyrifos $50 \%+$ Cypermethrin 5\% in-vitro and in-vivo.

\section{Materials and Methods}

Preparation of mother culture of $T$. harzianum

T. harzianum maintained in the Plant Pathology laboratory of ICRI Regional Station, Sakaleshpur was used. This isolate is being mass produced and used for disease management in spices. Mother culture of $T$. harzianum was prepared by growing on PDA $(20 \mathrm{ml})$ taken in low cost bottles. After inoculation with $T$. harzianum, the bottles were incubated for $8-10$ days at $24+1{ }^{\circ} \mathrm{C}$. Then distilled water was added to each bottle and harvested the spores into a beaker. Six bottles were used to prepare 1 liter of spore suspension.

\section{Growth and sporulation of T. harzianum on} organic substrates

Coir pith compost, rice husk and sugarcane bagasse are the various organic substrates used in this study in comparison with coffee husk (parchment). The substrates were sprinkled with water or $5 \%$ jaggery solution so as to obtain $50 \%$ moisture, filled $(250 \mathrm{~g})$ in poly propylene bags, sealed and sterilised. After reaching room temperature, each bag was inoculated with $10 \mathrm{ml}$ of spore suspension of $T$. harzianum taken in a sterile syringe and mixed thoroughly for uniform distribution of spores. Then the bags were incubated at room temperature. The population of $T$. harzianum was analyzed by serial dilution plate technique (SDPT) 15 days after inoculation (DAI), 30 DAI and 60 DAI. Aliquots $(1 \mathrm{ml})$ from the suitable dilution was mixed with Rose Bengal Agar (RBA) in petri plates and incubated for colony formation and recorded after 7-8 days. The number of colony forming units (cfu) was then converted to $\log$ values and analyzed by ANOVA using MSTATC software. Duncan's Multiple Range Test (DMRT) did the mean comparison.

\section{Treatments}

T1 Coir pith compost

T2 Coir pith compost $+5 \%$ Jaggery

T3 Sugarcane bagasse

T4 Sugarcane bagasse $+5 \%$ Jaggery

T5 Rice husk

T6 Rice husk + 5\% Jaggery

T7 Coffee husk parchment (control)

Replications: 3

Number of bags per replication: 12

In-vitro study on the compatibility of $T$. harzianum and insecticide combination Chlorpyrifos 50\% + Cypermethrin 5\%

The compatibility of $T$. harzianum and insecticide combination, Chlorpyrifos 50\%+ Cypermethrin $5 \%$ was studied by poisoned 
food technique on PDA medium. Requisite quantity of the insecticide was added to the PDA in order to get final concentrations of $55,83,110,138,165,193$ and 220ppm. In the first set of experiment, the insecticide was added to the autoclaved medium and then dispensed into petri plates (hence the insecticide was not heated). In the second set of experiment, the insecticide was added to the medium and then autoclaved and dispensed into the petri plates. The petri plates were then inoculated with $5 \mathrm{~mm}$ diameter mycelial disc of 3 days old culture of $T$. harzianum and incubated at room temperature. There were 8 treatments with 3 replications for each concentration of the insecticide. The radial growth of the colony was measured after 1 day, 2 days, 3 days, 4 days, 5 days, 10 days and 15 days of inoculation. The inhibition (\%) of the growth of $T$. harzianum due to the presence of insecticide was calculated using the formula, (Radial growth of $\mathrm{TH}$ in control plate Radial growth in treated plate) / Radial growth in control plate) $x 100$

The radial growth was analyzed by ANOVA and Duncan's Multiple Range Test (DMRT) did the mean comparison using the MSTATC software. The inhibition (\%) was transformed to corresponding angular values and analyzed by ANOVA and DMRT.

In-vivo study on the compatibility of $T$. harzianum and combination of insecticide Chlorpyrifos 50\% + Cypermethrin 5\% in soil

$100 \mathrm{~g}$ of shade dried soil was taken in plastic cups of $11.5 \mathrm{~cm}$ height $\times 11.5 \mathrm{~cm}$ diameter. Requisite quantity of the insecticide was added to the soil in order to get final concentration 55, 83,110, 138, 165, 193 and $220 \mathrm{ppm}$. $1 \mathrm{~g}$ of $T$. harzianum grown on coffee husk (parchment) was added to each cup and maintained at $24 \pm 2^{\circ} \mathrm{C}$ in a shade house for 30 days. Distilled water $(5-7 \mathrm{ml})$ was added weekly twice to retain the moisture in each cup. The population of $T$. harzianum was analyzed by serial dilution plate technique (SDPT) at 0 hour, 15 days after inoculation (DAI) and 30 DAI. The number of colony forming unit (cfu) was converted to corresponding log values and analyzed by ANOVA using MSTATC software. Duncan's Multiple Range Test (DMRT) did the mean comparison.

\section{Results and Discussion}

\section{Growth and sporulation of T. harzianum on organic substrates}

The growth and sporulation of $T$. harzianum on organic substrates like coir pith compost, rice husk, sugarcane bagasse etc was studied. The inoculated substrates were incubated and analyzed the cfu at periodical intervals. After 15 days of incubation colony forming units of $T$. harzianum in each treatment was found to be on par with each other and recorded colonies up to $10^{10}$ dilution. After 30 days, coffee husk $\left(\mathrm{T}_{7}\right)$ showed maximum number of cfu per gram of the substrate $\left(48 \times 10^{10}\right)$ followed by coir pith compost $\left(\mathrm{T}_{1} / 24.33 \times\right.$ $\left.10^{10}\right)$, sugarcane bagasse $+5 \%$ jaggery (T4 / $\left.26 \times 10^{10}\right)$ and rice husk $\left(\mathrm{T}_{5} / 43.33 \times 10^{10}\right)$ which were on par with each other. On further incubation up to 60 days, coir pith compost $\left(\mathrm{T}_{1} / 43 \times 1010\right)$, coir pith compost $+5 \%$ jaggery $\left(\mathrm{T}_{2} / 32.33 \times 10^{10}\right)$ and sugarcane bagasse $\left(\mathrm{T}_{3} / 21 \times 10^{10}\right)$ recorded maximum number of cfu followed by rice husk $\left(\mathrm{T}_{5} / 38\right.$ $\left.\times 10^{10}\right)$ and rice husk $+5 \%$ jaggery $\left(\mathrm{T}_{6} /\right.$ $\left.23.33 \times 10^{10}\right)$. In all the substrates, colonies were found in $10^{10}$ dilution and survived even up to 60 days of incubation (Table 1). Coir pith compost $\left(T_{1}\right)$ and sugarcane bagasse $\left(T_{3}\right)$ recorded more population than other substrates and hence could be used as alternate media in mass production. Earlier studies reported excellent multiplication of $T$. 
harzianum on coffee husk (Prakash et al., 1999; Saju et al., 2002).

In-vitro study on the compatibility of $T$. harzianum and insecticide combination Chlorpyrifos 50\% + Cypermethrin 5\%

When the insecticide was added to the autoclaved PDA and inoculated with $T$. harzianum, the radial growth of the colony was least in $\mathrm{T}_{7}(0.64 \mathrm{~cm})$ followed by $\mathrm{T}_{6}(0.75$ $\mathrm{cm})$ and $\mathrm{T}_{5}(0.86 \mathrm{~cm})$ which were on par with each other after 5 days of incubation as compared to control $\left(\mathrm{T}_{8} / 9.87 \mathrm{~cm}\right)$. Among $\mathrm{T}_{1}-\mathrm{T}_{4}$ growth of $T$. harzianum could be observed after 2 days, but in $\mathrm{T}_{5}$ and $\mathrm{T}_{6}$ growth could be seen only after 3 days and in $\mathrm{T}_{7}$ after 4 days. The inhibition (\%) of colony growth after 4 days of incubation was highest in $\mathrm{T}_{7}$ (91.66), $\mathrm{T}_{6}$ (91.53) and $\mathrm{T}_{5}$ (91.04) (Table 2). Similarly, after 5 days of incubation, inhibition (\%) was highest in $\mathrm{T}_{7}$ (97.78) followed by $\mathrm{T}_{6}$ (90.39). This was followed by $\mathrm{T}_{5}$ (88.99) and $\mathrm{T} 4$ (87.98) which were on par with each other. Even though the colony growth was very slow initially for 5 days, it continued to grow as evident from the measurements on 10th and 15th day.

When the insecticide was added to PDA, autoclaved and then inoculated with $T$. harzianum, the radial growth of the colony was least in $\mathrm{T}_{7}(0.70 \mathrm{~cm})$ and $\mathrm{T}_{6}(0.68 \mathrm{~cm})$ and $\mathrm{T}_{5}(0.69 \mathrm{~cm})$ which were on par with each other after 5 days of incubation. The inhibition (\%) of colony growth after 5 days of incubation was on par with each other in all the treatments (Table 3). Similar to the previous set of experiment, even though the $T$. harzianum was inhibited initially, it continued to grow as evident from the measurements on 10 th and 15 th day.

Table.1 Population (cfu) of Trichoderma harzianum on different substrates at periodical intervals

\begin{tabular}{lccc}
\hline \multirow{2}{*}{ Treatments } & \multicolumn{3}{c}{ No. of cfu x 10 } \\
\cline { 2 - 4 } & $\mathbf{1 5}$ days & $\mathbf{3 0 ~ d a y s}$ & $\mathbf{6 0 ~ d a y s}$ \\
\hline $\mathrm{T}_{1}$ Coir pith compost & $52.00(11.72)^{\mathrm{a}}$ & $24.33(11.51)^{\mathrm{ab}}$ & $43.00(11.63)^{\mathrm{a}}$ \\
$\mathrm{T}_{2}$ Coir pith compost + 5\% Jaggery & $43.66(11.31)^{\mathrm{a}}$ & $26.00(11.40)^{\mathrm{abc}}$ & $32.33(11.65)^{\mathrm{a}}$ \\
$\mathrm{T}_{3}$ Sugarcane bagasse & $56.00(11.74)^{\mathrm{a}}$ & $23.66(11.20)^{\mathrm{c}}$ & $21.00(11.61)^{\mathrm{a}}$ \\
$\mathrm{T}_{4}$ Sugarcane bagasse + 5\% Jaggery & $44.66(11.63)^{\mathrm{a}}$ & $26.00(11.49)^{\mathrm{ab}}$ & $24.00(11.43)^{\mathrm{b}}$ \\
$\mathrm{T}_{5}$ Rice husk & $23.33(11.36)^{\mathrm{a}}$ & $43.33(11.45)^{\mathrm{ab}}$ & $38.00(11.54)^{\mathrm{ab}}$ \\
$\mathrm{T}_{6}$ Rice husk + 5\% Jaggery & $27.33(11.42)^{\mathrm{a}}$ & $35.66(11.28)^{\mathrm{bc}}$ & $23.33(11.54)^{\mathrm{ab}}$ \\
$\mathrm{T}_{7}$ Coffee husk (Parchment) & $32.33(11.51)^{\mathrm{a}}$ & $48.00(11.53)^{\mathrm{a}}$ & $37.33(11.26)^{\mathrm{c}}$ \\
$\mathrm{CD}$ (p=0.05) & 0.4605 & 0.2320 & 0.1258 \\
\hline
\end{tabular}

cfu: colony forming units

Figures in parenthesis indicate logarithmic values

Means followed by the same alphabet(s) are not significantly different as per Duncan's Multiple Range Test 
Table.2 In-vitro study on the compatibility of Trichoderma harzianum and insecticide combination

Chlorpyrifos 50\% + Cypermethrin 5\% added after autoclaving

\begin{tabular}{|c|c|c|c|c|c|c|c|c|c|c|c|c|}
\hline \multirow{2}{*}{$\begin{array}{l}\text { Treatment } \\
\text { (Chlorpyrifos } \\
+ \\
\text { Cypermethrin) }\end{array}$} & \multicolumn{7}{|c|}{ Radial growth of colony $(\mathrm{cm})$} & \multicolumn{5}{|c|}{ Inhibition (\%) } \\
\hline & 1 day & 2 day & 3 day & 4 day & 5 day & 10 day & 15 day & 1 day & 2 day & 3 day & 4 day & 5 day \\
\hline $\mathrm{T}_{1} 55 \mathrm{ppm}$ & $0.25^{\mathrm{b}}$ & $0.60^{\mathrm{b}}$ & $0.85^{\mathrm{b}}$ & $1.13^{\mathrm{b}}$ & $1.50^{\mathrm{b}}$ & $2.48^{\mathrm{a}}$ & $4.43^{\mathrm{a}}$ & 91.37 & $\begin{array}{l}85.71 \\
(67.78)^{b}\end{array}$ & $\begin{array}{l}86.64 \\
(68.55)^{\mathrm{d}}\end{array}$ & $\begin{array}{l}85.12 \\
(67.30)^{\mathrm{d}}\end{array}$ & $\begin{array}{l}80.96 \\
(64.06)^{\mathrm{e}}\end{array}$ \\
\hline $\mathrm{T}_{2} 83 \mathrm{ppm}$ & $0.25^{\mathrm{b}}$ & $0.72^{\mathrm{b}}$ & $0.77^{b}$ & $0.87^{\text {bc }}$ & $1.22^{\mathrm{bc}}$ & $2.02^{\mathrm{ab}}$ & $4.50^{\mathrm{a}}$ & 91.37 & $\begin{array}{l}82.85 \\
(65.60)^{b}\end{array}$ & $\begin{array}{l}87.94 \\
(69.74)^{\mathrm{cd}}\end{array}$ & $\begin{array}{l}88.45 \\
(70.16)^{b c}\end{array}$ & $\begin{array}{l}84.47 \\
(66.73)^{\mathrm{d}}\end{array}$ \\
\hline $\mathrm{T}_{3} 110 \mathrm{ppm}$ & $0.25^{\mathrm{b}}$ & $0.60^{\mathrm{b}}$ & $0.76^{\mathrm{b}}$ & $0.90^{\mathrm{bc}}$ & $1.20^{\mathrm{bc}}$ & $1.66^{\mathrm{bc}}$ & $3.50^{\mathrm{b}}$ & 91.37 & $\begin{array}{l}85.71 \\
(67.78)^{b}\end{array}$ & $\begin{array}{l}87.99 \\
(69.71)^{\mathrm{cd}}\end{array}$ & $\begin{array}{l}88.15 \\
(69.83)^{c}\end{array}$ & $\begin{array}{l}84.77 \\
(67.01)^{\mathrm{d}}\end{array}$ \\
\hline $\mathrm{T}_{4} 138 \mathrm{ppm}$ & $0.25^{\mathrm{b}}$ & $0.60^{\mathrm{b}}$ & $0.61 b^{c}$ & $0.72^{\mathrm{c}}$ & $0.94^{b c}$ & $1.41^{\mathrm{cd}}$ & $2.23^{\mathrm{c}}$ & 91.37 & $\begin{array}{l}85.71 \\
(67.78)^{b}\end{array}$ & $\begin{array}{l}90.45 \\
(71.98)^{\mathrm{bc}}\end{array}$ & $\begin{array}{l}90.47 \\
(71.95)^{\mathrm{ab}}\end{array}$ & $\begin{array}{l}87.98 \\
(69.69)^{\mathrm{c}}\end{array}$ \\
\hline $\mathrm{T}_{5} 165 \mathrm{ppm}$ & $0.25^{\mathrm{b}}$ & $0.25^{\mathrm{c}}$ & $0.6 b^{c}$ & $0.68^{\mathrm{c}}$ & $0.86^{\mathrm{c}}$ & $1.44^{\mathrm{cd}}$ & $2.22^{\mathrm{c}}$ & 91.37 & $\begin{array}{l}94.04 \\
(75.82)^{\mathrm{a}}\end{array}$ & $\begin{array}{l}90.61 \\
(72.15)^{\mathrm{bc}}\end{array}$ & $\begin{array}{l}91.04 \\
(72.50)^{\mathrm{a}}\end{array}$ & $\begin{array}{l}88.99 \\
(70.57)^{\mathrm{c}}\end{array}$ \\
\hline $\mathrm{T}_{6} 193 \mathrm{ppm}$ & $0.25^{\mathrm{b}}$ & $0.25^{\mathrm{c}}$ & $0.53^{\mathrm{bc}}$ & $0.64^{\mathrm{c}}$ & $0.75^{\mathrm{c}}$ & $1.08^{\mathrm{de}}$ & $1.61^{\mathrm{cd}}$ & 91.37 & $\begin{array}{l}94.04 \\
(75.82)^{\mathrm{a}}\end{array}$ & $\begin{array}{l}91.65 \\
(73.25)^{\mathrm{b}}\end{array}$ & $\begin{array}{l}91.53 \\
(73.06)^{\mathrm{a}}\end{array}$ & $\begin{array}{l}90.39 \\
(71.92)^{b}\end{array}$ \\
\hline $\mathrm{T}_{7} 220 \mathrm{ppm}$ & $0.25^{\mathrm{b}}$ & $0.25^{\mathrm{c}}$ & $0.25^{\mathrm{c}}$ & $0.63^{\mathrm{c}}$ & $0.64^{\mathrm{c}}$ & $0.77^{\mathrm{e}}$ & $0.97^{\mathrm{d}}$ & 91.37 & $\begin{array}{l}94.04 \\
(75.82)^{\mathrm{a}}\end{array}$ & $\begin{array}{l}96.08 \\
(78.46)^{\mathrm{a}}\end{array}$ & $\begin{array}{l}91.66 \\
(73.19)^{\mathrm{a}}\end{array}$ & $\begin{array}{l}91.78 \\
(73.26)^{\mathrm{a}}\end{array}$ \\
\hline $\mathrm{T}_{8}$ Control & $2.90^{\mathrm{a}}$ & $4.20^{\mathrm{a}}$ & $6.39^{\mathrm{a}}$ & $7.60^{\mathrm{a}}$ & $7.87^{\mathrm{a}}$ & - & - & - & - & - & - & - \\
\hline $\mathrm{CD}(\mathrm{p}=0.05)$ & 0.110 & 0.207 & 0.375 & 0.363 & 0.626 & 0.556 & 0.767 & - & 2.211 & 2.704 & 2.038 & 1.290 \\
\hline
\end{tabular}


Table.3 In-vitro study on the compatibility of Trichoderma harzianum and insecticide combination Chlorpyrifos 50\% + Cypermethrin 5\% added before autoclaving

\begin{tabular}{|c|c|c|c|c|c|c|c|c|c|c|c|c|}
\hline \multirow{2}{*}{$\begin{array}{l}\text { Treatment } \\
\text { (Chlorpyrifos + } \\
\text { Cypermethrin) }\end{array}$} & \multicolumn{7}{|c|}{ Radial growth of colony $(\mathbf{c m})$} & \multicolumn{5}{|c|}{ Inhibition (\%) } \\
\hline & 1 day & 2 day & 3 day & 4 day & 5 day & 10 day & 15 day & 1 day & 2 day & 3 day & 4 day & 5 day \\
\hline $\mathrm{T}_{1} 55 \mathrm{ppm}$ & $0.25^{\mathrm{b}}$ & $0.60^{\mathrm{b}}$ & $0.82^{b}$ & $1.23^{\mathrm{b}}$ & $1.45^{\mathrm{b}}$ & $2.25^{\mathrm{a}}$ & $3.23^{\mathrm{a}}$ & 91.37 & 85.71 & $\begin{array}{l}87.16 \\
(68.99)^{b}\end{array}$ & $\begin{array}{l}83.76 \\
(66.36)^{\mathrm{a}}\end{array}$ & $\begin{array}{l}81.55 \\
(64.84)^{\mathrm{a}}\end{array}$ \\
\hline $\mathrm{T}_{2} 83 \mathrm{ppm}$ & $0.25^{\mathrm{b}}$ & $0.60^{\mathrm{b}}$ & $0.85^{\mathrm{b}}$ & $1.06^{\mathrm{bc}}$ & $1.23^{\mathrm{bc}}$ & $1.96^{\mathrm{a}}$ & $2.22^{\mathrm{b}}$ & 91.37 & 85.71 & $\begin{array}{l}86.59 \\
(68.47)^{b}\end{array}$ & $\begin{array}{l}85.96 \\
(68.01)^{\mathrm{a}}\end{array}$ & $\begin{array}{l}84.34 \\
(66.67)^{\mathrm{a}}\end{array}$ \\
\hline $\mathrm{T}_{3} 110 \mathrm{ppm}$ & $0.25^{\mathrm{b}}$ & $0.60^{\mathrm{b}}$ & $0.71^{\mathrm{b}}$ & $0.82^{\mathrm{bcd}}$ & $0.85^{\mathrm{bc}}$ & $0.96^{\mathrm{b}}$ & $1.03^{\mathrm{c}}$ & 91.37 & 85.71 & $\begin{array}{l}88.83 \\
(70.45)^{b}\end{array}$ & $\begin{array}{l}89.20 \\
(70.81)^{\mathrm{a}}\end{array}$ & $\begin{array}{l}89.12 \\
(70.81)^{\mathrm{a}}\end{array}$ \\
\hline $\mathrm{T}_{4} 138 \mathrm{ppm}$ & $0.25^{\mathrm{b}}$ & $0.60^{\mathrm{b}}$ & $0.69^{\mathrm{b}}$ & $0.80^{\mathrm{bcd}}$ & $0.82^{\mathrm{bc}}$ & $0.86^{\mathrm{b}}$ & $0.91^{\mathrm{c}}$ & 91.37 & 85.71 & $\begin{array}{l}89.19 \\
(70.78)^{b}\end{array}$ & $\begin{array}{l}89.46 \\
(71.08)^{\mathrm{a}}\end{array}$ & $\begin{array}{l}89.54 \\
(71.20)^{\mathrm{a}}\end{array}$ \\
\hline $\mathrm{T}_{5} 165 \mathrm{ppm}$ & $0.25^{\mathrm{b}}$ & $0.25^{\mathrm{c}}$ & $0.62^{\mathrm{b}}$ & $0.68^{\mathrm{cd}}$ & $0.69^{c}$ & $0.69^{\mathrm{b}}$ & $0.74^{\mathrm{c}}$ & 91.37 & 94.04 & $\begin{array}{l}90.29 \\
(71.82)^{\mathrm{b}}\end{array}$ & $\begin{array}{l}91.04 \\
(72.56)^{\mathrm{a}}\end{array}$ & $\begin{array}{l}91.23 \\
(72.73)^{\mathrm{a}}\end{array}$ \\
\hline $\mathrm{T}_{6} 193 \mathrm{ppm}$ & $0.25^{\mathrm{b}}$ & $0.25^{\mathrm{c}}$ & $0.60^{\mathrm{b}}$ & $0.61^{\mathrm{d}}$ & $0.68^{c}$ & $0.75^{\mathrm{b}}$ & $0.82^{\mathrm{c}}$ & 91.37 & 94.04 & $\begin{array}{l}90.61 \\
(72.15)^{\mathrm{b}}\end{array}$ & $\begin{array}{l}91.97 \\
(73.54)^{\mathrm{a}}\end{array}$ & $\begin{array}{l}91.36 \\
(72.83)^{\mathrm{a}}\end{array}$ \\
\hline $\mathrm{T}_{7} 220 \mathrm{ppm}$ & $0.25^{\mathrm{b}}$ & $0.25^{\mathrm{c}}$ & $0.25^{\mathrm{c}}$ & $0.63^{\mathrm{cd}}$ & $0.70^{c}$ & $0.71^{\mathrm{b}}$ & $0.75^{\mathrm{c}}$ & 91.37 & 94.04 & $\begin{array}{l}96.08 \\
(78.46)^{\mathrm{a}}\end{array}$ & $\begin{array}{l}91.66 \\
(73.19)^{\mathrm{a}}\end{array}$ & $\begin{array}{l}91.11 \\
(72.63)^{\mathrm{a}}\end{array}$ \\
\hline $\mathrm{T}_{8}$ Control & $2.90^{\mathrm{a}}$ & $4.20^{\mathrm{a}}$ & $6.39^{\mathrm{a}}$ & $7.60^{\mathrm{a}}$ & $7.87^{\mathrm{a}}$ & - & - & - & - & - & - & - \\
\hline $\mathrm{CD}(\mathrm{p}=0.05)$ & 0.110 & 0.156 & 0.327 & 0.449 & 0.749 & 0.337 & 0.377 & - & - & 3.816 & 13.16 & 16.91 \\
\hline
\end{tabular}

Figures in parenthesis indicate arc sin transformations

Means followed by the same alphabet (s) are not significantly different as per Duncan's Multiple Range Test 
Table.4 In-vivo study on the compatibility of Trichoderma harzianum and combination of insecticide Chlorpyrifos 50\% + Cypermethrin 5\% in soil

\begin{tabular}{llll}
\hline $\begin{array}{l}\text { Treatment } \\
\text { (Chlorpyrifos }+\end{array}$ & \multicolumn{3}{c}{ No. of cfu x 10 } \\
Cypermethrin) & 0 Hour & \multicolumn{1}{c}{ 15 DAI } & \multicolumn{1}{c}{ 30 DAI } \\
\cline { 2 - 4 } $\mathrm{T}_{1} 55 \mathrm{ppm}$ & $10(10.97)^{\mathrm{a}}$ & $14(11.12)^{\mathrm{a}}$ & $10(11.00)^{\mathrm{a}}$ \\
$\mathrm{T}_{2} 83 \mathrm{ppm}$ & $2(10.35)^{\mathrm{b}}$ & $12(11.07)^{\mathrm{a}}$ & $11(11.02)^{\mathrm{a}}$ \\
$\mathrm{T}_{3} 110 \mathrm{ppm}$ & $4(10.61)^{\mathrm{ab}}$ & $14(11.12)^{\mathrm{a}}$ & $9(10.93)^{\mathrm{a}}$ \\
$\mathrm{T}_{4} 138 \mathrm{ppm}$ & $6(10.75)^{\mathrm{ab}}$ & $3(10.51)^{\mathrm{a}}$ & $5(10.63)^{\mathrm{a}}$ \\
$\mathrm{T}_{5} 165 \mathrm{ppm}$ & $9(10.95)^{\mathrm{ab}}$ & $6(10.64)^{\mathrm{a}}$ & $3(10.51)^{\mathrm{a}}$ \\
$\mathrm{T}_{6} 193 \mathrm{ppm}$ & $7(10.85)^{\mathrm{ab}}$ & $5(10.68)^{\mathrm{a}}$ & $4(10.58)^{\mathrm{a}}$ \\
$\mathrm{T}_{7} 220 \mathrm{ppm}$ & $6(10.74)^{\mathrm{ab}}$ & $5(10.68)^{\mathrm{a}}$ & $4(10.54)^{\mathrm{a}}$ \\
$\mathrm{T}_{8}$ Control & $13(11.11)^{\mathrm{a}}$ & $17(11.23)^{\mathrm{a}}$ & $15(11.15)^{\mathrm{a}}$ \\
$\mathrm{CD}(\mathrm{p}=0.05)$ & 0.606 & 1.006 & 0.743 \\
\hline
\end{tabular}

cfu: colony forming units; Figures in parenthesis indicate logarithmic values

Means followed by the same alphabet(s) are not significantly different as per Duncan's Multiple Range Test

The concentration of insecticide for soil drenching in black pepper is $200 \mathrm{ml}$ per 100 liters that would give $83 \mathrm{ppm}$ solution. Hence, concentration below and above the recommended dose were studied here. The insecticide Chlorpyrifos was already known to be compatible with T. harzianum (Stephen et al., 2000). However, in this study when the combination of Chlorpyrifos 50\%+ Cypermethrin 5\% was used it was found to slow down the radial growth of $T$. harzianum initially for 5 days. Therefore it implies that the Cypermethrin is effecting the growth of $T$. harzianum initially even at $55 \mathrm{ppm}$. It is possible since the $T$. harzianum comes in direct contact with the insecticide molecules during in-vitro studies. However, the fungus continued to grow after initial suppression as evident from the measurements on 10th and 15th day. This shows the partial compatibility of the insecticide combination and $T$. harzianum in in-vitro condition.

In-vivo study on the compatibility of $T$. harzianum and combination of insecticide Chlorpyrifos 50\% + Cypermethrin 5\% in soil

The number of cfu recorded at 0 hour slightly varied in different treatments. This might be due to handling error and such variations are not expected since uniform quantities were added in each treatment. The cfu in all the treatments were on par with each other at 15 DAI which showed that the addition of insecticide into soil did not affect the population of $T$. harzianum. Colonies were noted even at $10^{10}$ dilution (Table 4). Similarly at 30 DAI, the cfu present in all the treatments were also on par with each other. Colonies were present even at $10^{10}$ dilution. Hence it is implied that the insecticide did not affect the population of $T$. harzianum in invivo conditions. Stephen et al. (2000) noted similar observations with $T$. harzianum and Chlorpyrifos.

The combination of insecticide has entered in to the market very recently. The in-vitro study conducted here gives an indication that care should be taken to avoid direct contact of the $T$. harzianum and the insecticide so that benefits of both are made available for the protection of black pepper. One strategy that is employed with other incompatible chemicals is that there would be a time gap given in between the application of $T$. harzianum and the chemical so that the direct contact is avoided thereby damage to its 
propagules minimized. It may be further noted that even though the insecticide showed partial incompatibility with $T$. harzianum in in-vitro test, the concentration is further diluted when we drench the same to the root zone which consists of $\sim 500 \mathrm{~kg}$ of soil and receives $\sim 5$ liter of drenching solution. That is why in in-vivo studies the insecticide doses could not affect the $T$. harzianum propagules and showed compatible for field application.

\section{Acknowledgements}

The work forms part of the MSc dissertation submitted by the first author to the University of Mysore, Manasagangothri and expresses his gratitude to the Chairman, Spices Board, Kochi and the Director (Research), Indian Cardamom Research Institute, Myladumpara, Idukki District, Kerala for granting permission to carry out the study in ICRI Regional Station, Sakleshpur.

\section{References}

Ashwini, T., Rajesh, K., Nandini, G. and Shailesh, P. 2012. Compatibility of Trichoderma viride for selected fungicides and botanicals. Int. J. Plant Path., 3: 89-94.

Prakesh, M.G., Vinayagopal, K., Anandaraj, M. and Sarma, Y.R. 1999. Evaluation of substrates for mass multiplication of fungal biocontrol agents Trichoderma harzianum and Trichoderma virens. J. Spices and Aromatic Crops, 8: 207-210.

Rini, C.R. and Sulochana, K.K. 2007. Substrate evaluation for multiplication of Trichoderma spp. J. Tropical Agric., 45: 58-60.

Saju, K.A., Anandaraj, M. and Sarma, Y.R. 2002. On farm production of Trichoderma harzianum using organic matter. Indian Phytopath., 55: 227-281.

Saxena, D., Tewari, A.K. and Rai, D. 2014. The in-vitro effect of some commonly used fungicides, insecticides and herbicides for their compatibility with Trichoderma harzianum PBT23. World Appl. Sci. J., 31: 444-448.

Stephen, R.J., Anandaraj, M. and Sarma, Y.R. 2000. Compatibility of phorate and chlorpyrifos with $T$. harzianum (Rifai.) applied for integrated disease management in black pepper (Piper nigrum L). J. Spices and Aromatic Crops, 9: 111-115.

Thiruchchelvan, N., Mikunthan, G., Thirukkumaran, G. and Pakeerathan, K. 2013. Effect of insecticides on bio-agent Trichoderma harzianum Rifai under invitro condition. American Eurasian J. Agric. and Environ. Sci., 13: 13571360.

Vinit, P.S., Seweta, S., Swapnil, K.S. and Singh, H.B. 2012. Compatibility of different insecticides with Trichoderma harzianum under in-vitro condition. $J$. Plant Path., 11: 73-76.

\section{How to cite this article:}

Siddhartha, N.S., K.V. Amara, K.A. Ramya Mol, K.A. Saju, K.N. Harsha, P. Sharanappa and Pradip Kumar, K. 2017. Evaluation of Substrates for Mass Production of Trichoderma harzianum and its Compatibility with Chlorpyrifos + Cypermethrin. Int.J.Curr.Microbiol.App.Sci. 6(8): 3628-3635. doi: https://doi.org/10.20546/ijcmas.2017.608.437 